\title{
Well Differentiated Fibrosarcoma
}

National Cancer Institute

\section{Source}

National Cancer Institute. Well Differentiated Fibrosarcoma. NCI Thesaurus. Code C9025.

A well-differentiated malignant neoplasm arising from the deep soft tissues. It is

characterized by the presence of spindle-shaped fibroblasts and collagenous stroma formation in a herring bone growth pattern. 